\title{
$\begin{array}{lllllllllllllllll}\mathbf{K} & \mathbf{O} & \mathbf{M} & \mathbf{U} & \mathbf{N} & \mathbf{I} & \mathbf{K} & \mathbf{A} & \mathbf{T} & \mathbf{Y} & \mathbf{N} & \mathbf{A} & \mathbf{U} & \mathbf{K} & \mathbf{O} & \mathbf{W} & \mathbf{E}\end{array}$ \\ KWARTALNIK HISTORII KULTURY MATERIALNEJ 67 (4), 2019 \\ PL ISSN 0023-5881 \\ www.iaepan.edu.pl \\ DOI: 10.23858/KHKM67.2019.4.007
}

Jakub Sawicki

\section{A unique late medieval framed purse from New Market (Nowy Targ) square in Wrocław ${ }^{1}$}

Key words: medieval purse, small finds, dress accessories, object biography, Słowa kluczowe: średniowieczne sakiewki, zabytki wydzielone, akcesoria stroju, biografia przedmiotów

Purses, pouches, bags and other containers to carry things, especially medieval ones, are a rather specific and narrow case for very specialized material culture studies. From the archaeological point of view those objects seem to be one of the least studied category of leather artefacts. This is especially visible in contrast to the number of publications about shoes ${ }^{2}$ or even scabbards ${ }^{3}$. However, it is important to note that leather containers are rare archaeological finds, and only few assemblages from the territory of modern Poland were published ${ }^{4}$. On the other hand, purses and other bags are quite often mentioned in context of ornate decorations and their symbolic meaning 5 .

The specimen in question, documented with the inventory number 528/11/S (Figs 1,2) was found at the New Market (Nowy Targ) square in Wrocław, Poland (Fig. 3) during rescue excavations conducted in 2010-2012, covering an area of 0,4 ha. The New Market square was a very important place on the map of medieval Wrocław. Relics of the 12th and 13th century settlement have been found there and the area had served as a market square since the second half of 13 th century ${ }^{6}$. The purse is a part of a large assemblage, consisting of more than 60,000 pieces of leather recovered from the same site, but being the only one of its kind ${ }^{7}$.

The specimen from Wrocław's New Market square has a simple wooden ring and a bag part made of poor quality leather (Figs 1,2). The bag itself has dimension of $16,8 \times 22,4 \mathrm{~cm}$ and is made from 4 separate leather pieces and a wooden frame. The main body of the bag consists of one large, originally trapezoid or rectangular piece of leather sewn together in the front with a small triangle patch added at the bottom. It was joined with a careful overlapping seam with holes at regular distances, measuring approximately 3-4 mm between each other. In contrast, the wooden ring was stitched to the main body of the bag with a flat strap (thong) that was pulled

${ }^{1}$ This work was supported by the Czech Science Foundation, grant number 18-26503S.

${ }^{2}$ Grew F., De Neergaard M. 2006; Kowalska A.B. 2015; Konczewska M. 2018a; Konczewska M. 2018b.

${ }^{3}$ Cowgill J., De Neergaard M., Griffiths N. 2008.

${ }^{4}$ See Wywrot-Wyszkowska B. 2008, p. 68-73; Drążkowska A. 2009; Marcinkowski M. 2009, p. 171; Konczewska M. 2010, p. 244-245; Blusiewicz K. 2017, p. 340-341; Ceynowa B. 2018, p. 478-479.

${ }^{5}$ Ceynowa B. 2015; Wachowski K. 2013, there more literature.

${ }^{6}$ Mackiewicz M., Marcinkiewicz K., Piekalski J. 2014; Rytm rozwoju miasta. 2018.

7 Leather finds from this site were recently published by Magdalena Konczewska (Konczewska M. 2018a; Konczewska M. 2018b), but purses were only briefly mentioned. 


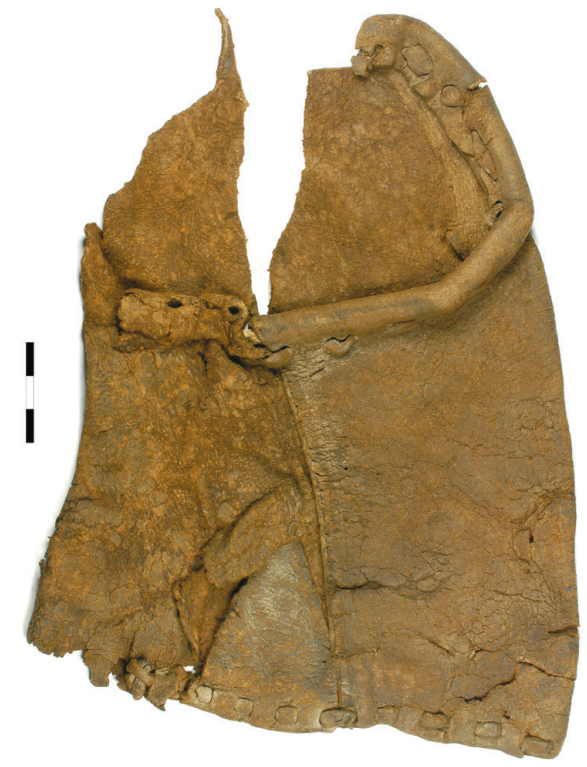

a

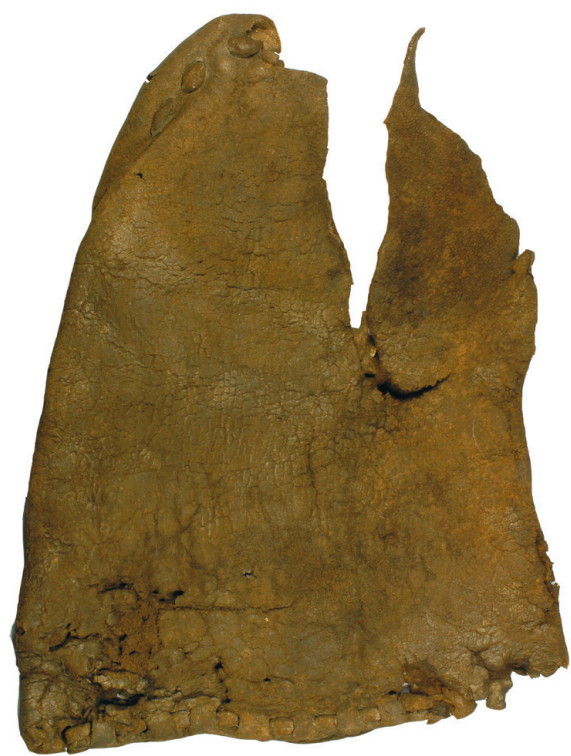

b

Fig. 1. Leather framed purse with a wooden ring from Wrocław, New Market Square (Inventory No 528/11/S): a — front side, b — back side. Photo by J. Sawicki

Ryc. 1. Skórzana sakiewka z ramką z obręczą wykonaną z drewna, Wrocław, pl. Nowy Targ (nr inw. 528/11/S): a — przód, b - tył. Foto J. Sawicki

through vertical holes. The same technique was used for sewing the bottom. The holes for the thong are cut quite carefully with ca $0,7-0,9 \mathrm{~cm}$ spacing. The seam on the bottom, at first glance, seems not to hold the contents inside well enough, but the thick strap probably kept the material together better than the thread. The leather was identified ${ }^{8}$ as a leather from an adult goat or sheep, tanned with fur/hair on. It indicates that the leather might have not been prepared professionally 9 .

As far as I know, there are currently no known direct analogies to the purse in question. Some examples of purses with ring frames and of only preserved frames are described below. However, all of them come from territories outside of modern Poland and none of those frames are made of wood.

The artefact from Wrocław can be identified as a so-called ring-framed purse. This kind of purses is one of the most distinctive types of (mostly) leather bags. Their metal components and construction were presented by Olaf Goubitz in his major work Purses in pieces ${ }^{10}$. They are further divided into subgroups, based on the type of frame ${ }^{11}$. This kind of purses is often referred

${ }^{8}$ I would like to thank Magdalena Konczewska from Institute of Archaeology at University of Wrocław, for providing this information.

9 See more about preparation of hides in Konczewska M. 2018 b, p. 753.

10 Goubitz O. 2009.

${ }^{11}$ Among them are also recently published spring-catch framed purses from Wrocław, see Sawicki J. 2014. 


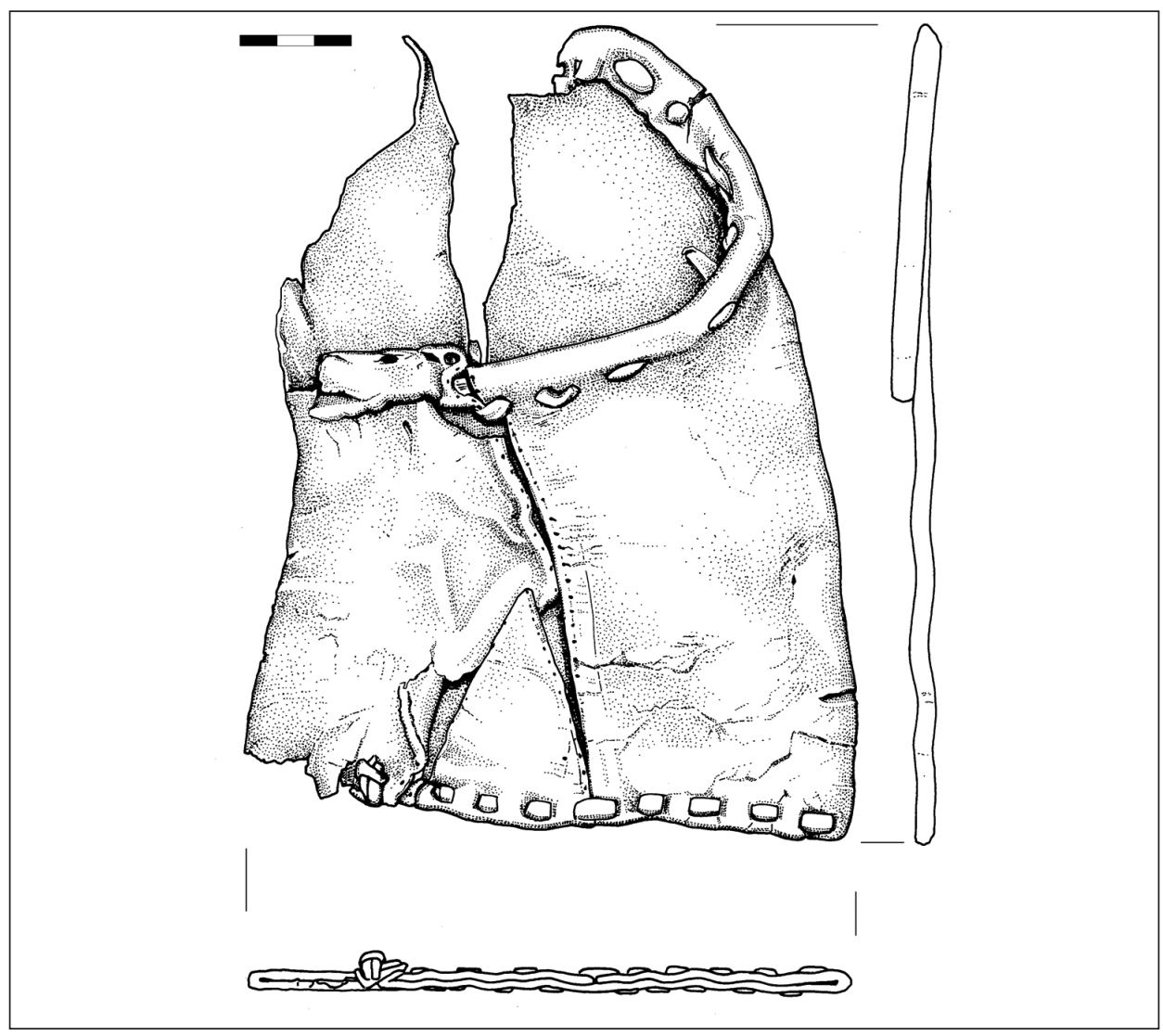

Fig. 2. Leather framed purse with a wooden ring from Wrocław, New Market Square (Inventory No 528/11/S). Drawing by T. Demidziuk

Ryc. 2. Skórzana sakiewka z ramką z obręczą wykonaną z drewna, Wrocław, pl. Nowy Targ (nr inw. 528/11/S). Rys. T. Demidziuk

to as falconry purses, and in German they are also called Jagdtasche (Hunting bags) (Fig. 4) ${ }^{12}$. Associating single ring-framed purses mostly with hunting activities seems to be correct not for the Middle Ages but for the later periods. Olaf Goubitz states that relating those bags to falconry is a misconception, as they are often visible in medieval iconography being worn by farmers, burghers and nobility ${ }^{13}$.

The bag parts of ring-framed purses were usually made of leather, as well as of textiles ${ }^{14}$. Those were sown onto the purse's ring which ought to be wide enough to put a hand through it to allow easier access to the inside of the purse. The hole in the specimen from New Market Square could have measured about $12 \mathrm{~cm}$ in diameter.

12 On this picture from Codex Manesse, ring framed purse is shown in a hunting scene. However, similar purses are also represented in the same codex in a completely different context - see miniature presenting courtly scene where Minnesinger Dietmar von Aist dressed as a merchant offers a brooch to a fair lady, Rosenheim K. von. 2019.

13 Goubitz O. 2009, p. 47-48.

${ }^{14}$ Goubitz O. 2009, p. 47; Ceynowa B. 2015, p. 78. 


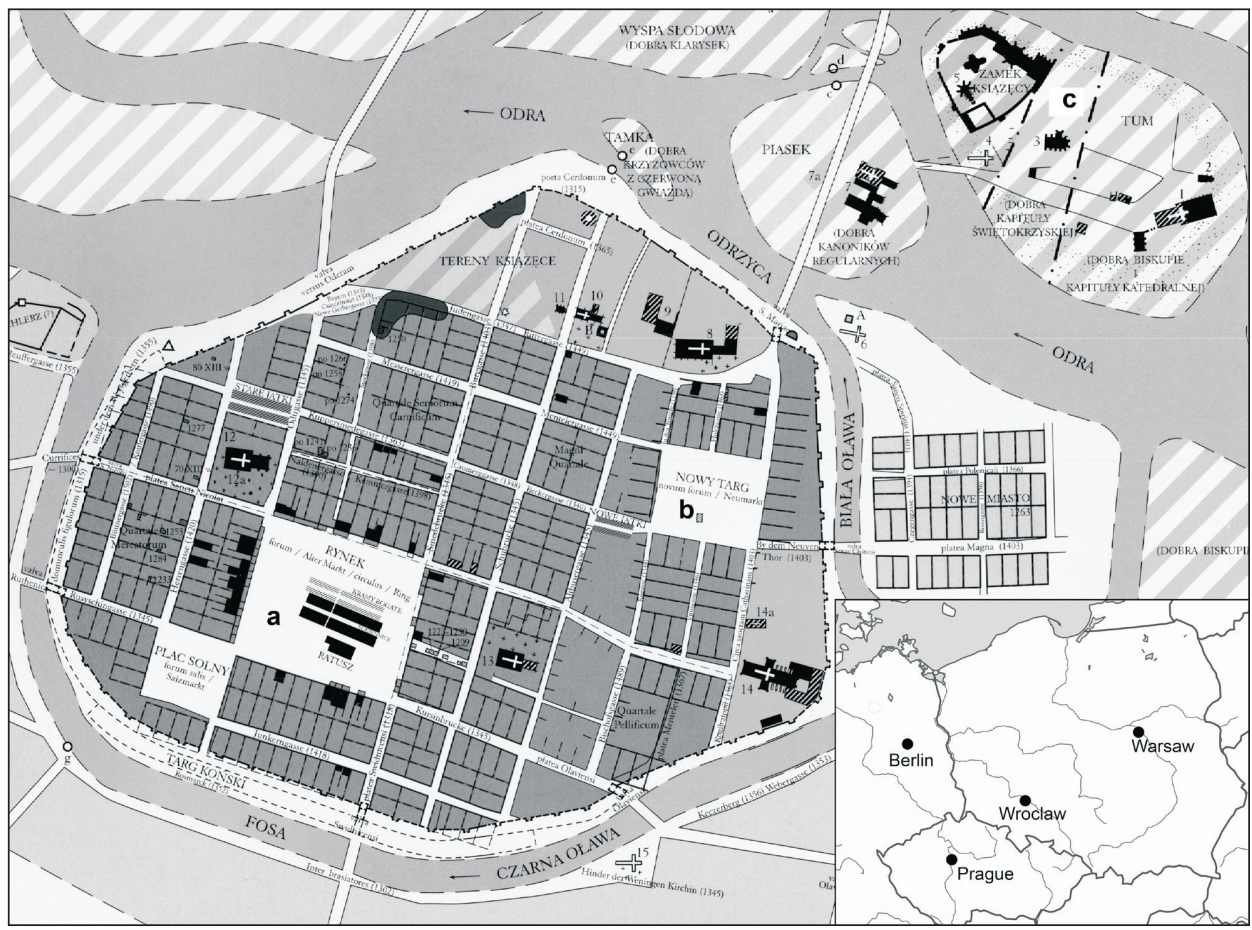

Fig. 3. Map of Wrocław in the 2nd half of the 13th century: a - Market Square (Rynek); b - New Market Square (pl. Nowy Targ); c — Cathedral Island (Ostrów Tumski). Source: Atlas historyczny miast polskich. 2001, map 3

Ryc. 3. Mapa Wrocławia w 2 poł. XIII wieku: a — Rynek; b - pl. Nowy Targ; c — Ostrów Tumski. Źródło: Atlas historyczny miast polskich. 2001, mapa 3

Most of the purses finds are represented only by the frame itself, which was usually made of iron, tin-coated iron, copper alloys, silver or even gold $^{15}$. One such specimen is known from the History Museum in Dresden (Fig. 5). It is much later than the New Market object, as it is dated to the year 1624, which also shows how long this type of purses was in use. It was made from the finest materials: gold, silver, silk and velvet ${ }^{16}$.

Among ring-framed purses various subtypes are distinguished. The distinction is based on the number of frames (eg. double frames) ${ }^{17}$ or frames mutual relation (eg. secondary-ring framed purses, which contain a smaller purse inside frame, joined with a single hinge) (Fig. 6).

Purse from New Market square in Wrocław can be dated to the period between the second half of 13th century and the first third of the 14th century. It was found on the square 63, quarter $\mathrm{A} / \mathrm{C}$ in the stratigraphic unit 22. This stratigraphic unit is interpreted with one of the main layers covering the whole excavated area and is assigned to phase 5, which is the early stage of the usage of the market square ${ }^{18}$. It covers the processes directly after setting out and paving the square in the second half of the13th c. In the whole stratigraphic unit 22 there were

\footnotetext{
15 Goubitz O. 2009, s. 47.

16 Jagdtasche. 2019.

17 Goubitz O. 2009, s. 50.

${ }_{18}$ Mackiewicz M., Marcinkiewicz K., Piekalski J. 2014; Marcinkiewicz K., Piekalski J. 2018.
} 


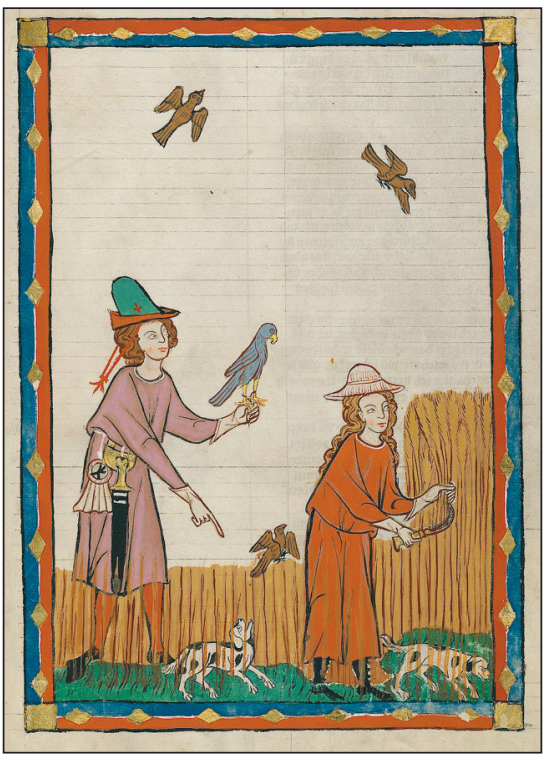

Fig. 4. Kunz von Rosenheim, picture from Codex Manesse, dated ca 1305-1340.

Source: Rosenheim K. von. 2019, http://digi.ub.uni-heidelberg.de/diglit/ cpg848/0783

Ryc. 4. Kunz von Rosenheim, miniatura z Codex Manesse, datowana ok. 1305-1340. Źródło: Rosenheim K. von. 2019, http://digi.ub.uni-heidelberg.de/diglit/ cpg848/0783

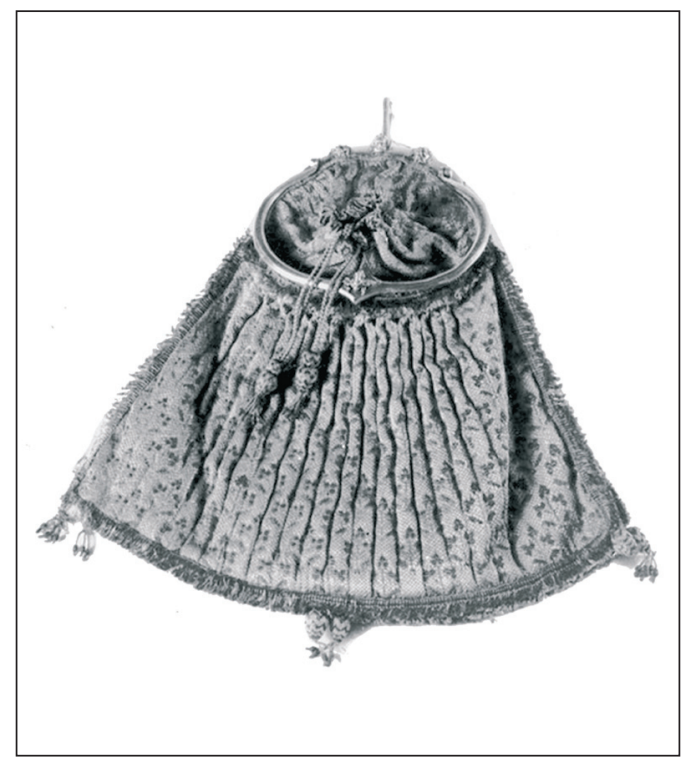

Fig. 5. Ring framed purse - hunting purse by Abraham Schwedler, dated 1624 .

Source: Schwedler A. 2019, https://www.bildindex.de/document/ obj32005248

Ryc. 5. Sakiewka z ramką — torebka myśliwska wykonana przez Abrahama Schwedlera, $1624 \mathrm{r}$.

Źródło: Schwedler A. 2019, https://www.bildindex.de/document/ obj32005248

over 600 fragments of leather ${ }^{19}$, however not grouped in one area but distributed loosely across the whole market square space ${ }^{20}$, and as such it is difficult to discuss production on market square in that phase.

Most of the artefacts in museum collections are much younger than 13 th $c .{ }^{21}$ Olaf Goubitz even suggests that they were depicted only since ca 1425 . However, they are known from previously mentioned Codex Manesse ${ }^{22}$, which can be dated to ca 1300-1340 ${ }^{23}$. The Wrocław find seems to be the oldest known example of a ring-framed purse.

The much later chronology of framed-purses finds and depictions of such objects in the iconography and the difference in the quality of materials rise the question of the Wrockaw object's biography ${ }^{24}$. I will briefly discuss if this wooden framed-purse is a rare imitation of more luxurious objects or was a completely common utilitarian item.

19 Marcinkiewicz K., Piekalski J. 2018, p. 154.

${ }^{20}$ Konczewska M. 2018b, p. 785, Fig. 690.

${ }^{21}$ See Goubitz O. 2009, p. 47-50.

22 See Fig. 3 and note 11.

23 Rosenheim K. von. 2019.

${ }^{24}$ Discussion on object biographies see: Kopytoff I. 2013; Social life. 2013; some remarks on interpreting material culture from economic and social perspectives see: Howell M. 2010; Jervis B. 2017. 


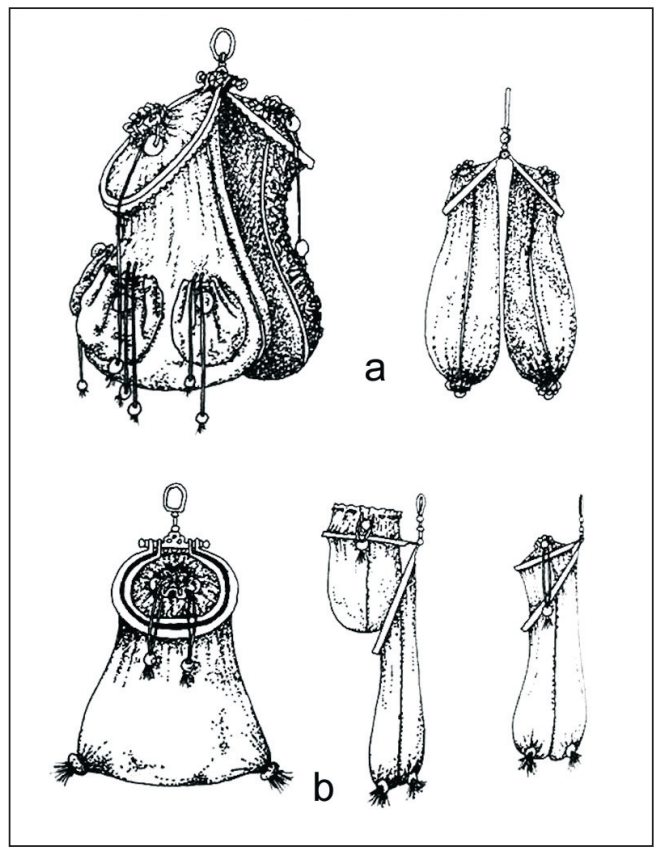

Fig. 6. Different types of ring-framed purses: $\mathrm{a}$ - double ring-framed purse; $\mathrm{b}$ - secondary-ring framed purse.

Source: Goubitz O. 2009, p. 50, Figs 76-77

Ryc. 6. Różne typy sakiewek z ramką: $\mathrm{a}$ - sakiewka z podwójną obręczą; $\mathrm{b}$ - sakiewka $\mathrm{z}$ dodatkową obręczą.

Źródło: Goubitz O. 2009, s. 50, ryc. 76-77

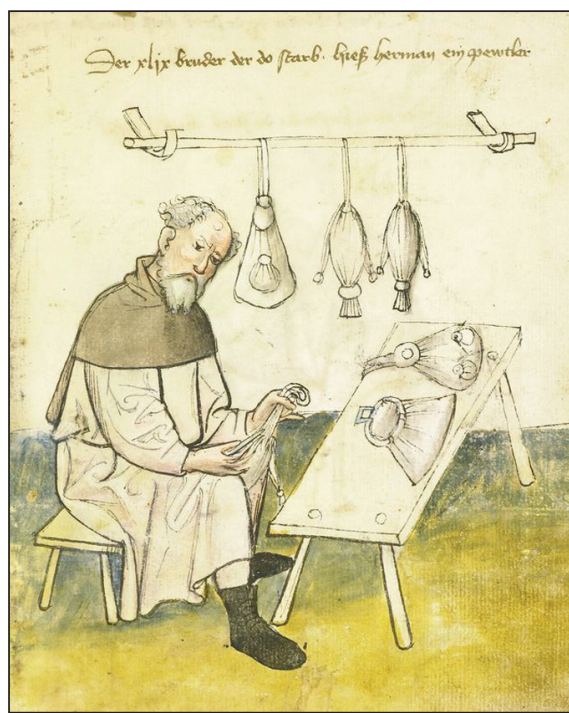

Fig. 7. The purse maker (German Beutler) at his workshop, picture from Die Nürnberger Hausbücher, dated ca 1425.

Source: Herman (Hermann). 2019, http://www.nuernberger-hausbuecher.de/ 75-Amb-2-317-22-r/data

Ryc. 7. Kaletnik (niem. Beutler) w swojej pracowni, rycina z Die Nürnberger Hausbücher, ok. 1425.

Źródło: Herman (Hermann). 2019, http://www.nuernberger-hausbuecher.de/ 75-Amb-2-317-22-r/data

Most finds of ring-framed purses consist only of the ring itself. Known artefacts are usually decorated. Some specimens are of elaborate design and made of iron ${ }^{25}$, but some are simple cast pieces from copper alloys ${ }^{26}$. Such simple objects with (probably) metal frames are found in the iconography, e.g. in depictions of craftsmen's trade (Fig. 7) and of peasants at work, who are shown in rugged clothes wearing simple framed purses (Fig. 8) ${ }^{27}$. However, the iconographic sources bring also examples of which should be considered the 'highest class' of objects, as they are richly decorated, e.g. with architectonic motives on frames, and are depicted as made of gold (Fig. 9). Similar purses are known from museum collections ${ }^{28}$.

The New Market square purse is definitely not a master class artefact, as it is made of poor quality leather with a wooden frame. According to the analysis conducted by Magdalena

${ }_{25}$ Goubitz O. 2009, p. 49, Fig. 72.

${ }^{26}$ Egan G., Pritchard F. 2002, p. 237, 357.

${ }^{27}$ Here it is worth to note, that purses shown at Fig. 7 have an alternative way of attaching it to a belt. Most known finds have a single suspensor connecting frame with belt. Specimens in question have one strap sewn on opposite sides of the frame. Purse from Nowy Targ Square has no traces of any kind of suspensor nor a strap, but it is partially broken in its upper part.

${ }_{28}$ Among others in the Kunsthistorisches Museum in Vienna, Jagdtasche. 2019. 


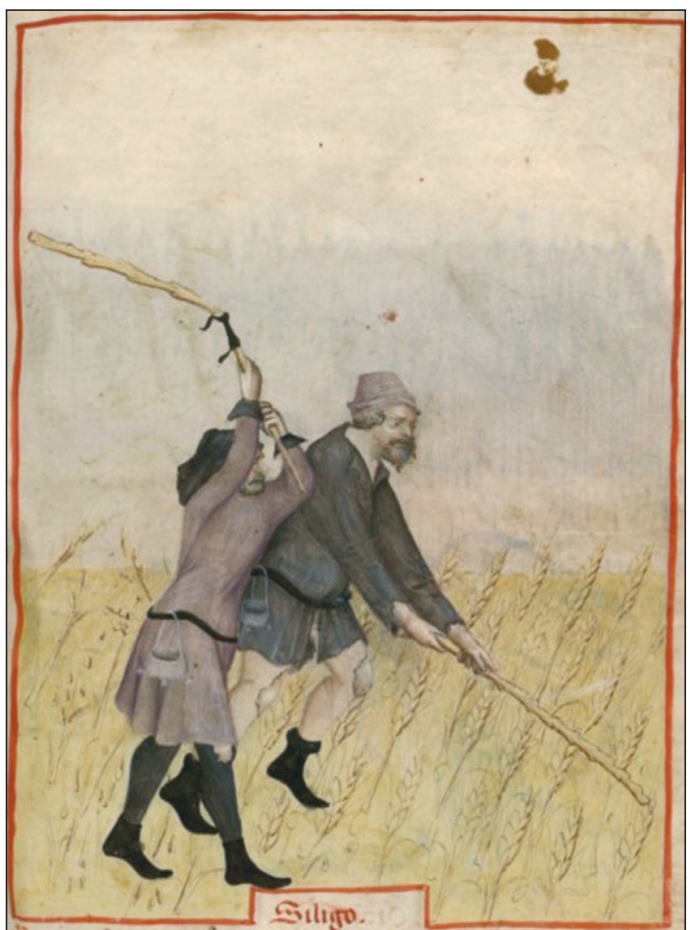

Fig. 8. Wheat Threshing, Tacuinum Sanitatis, dated 15th century. Source: Tacuinum Sanitatis. 2019, http://expositions.bnf.fr/gastro/grands/033.htm

Ryc. 8. Młócenie pszenicy, Tacuinum Sanitatis, XV w. Źródło:Tacuinum Sanitatis. 2019, http://expositions.bnf.fr/gastro/grands/033.htm

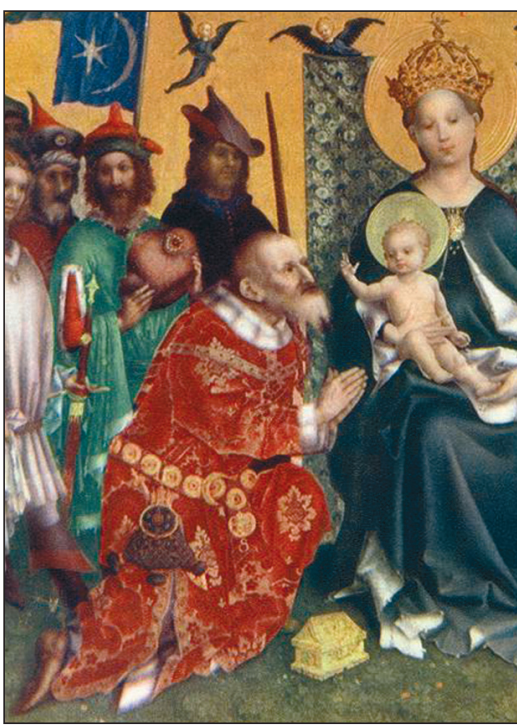

Fig. 9. Part of Adoration of the Magi by Stefan Lochner, dated ca 1440.

Source: Lochner S. 2019, https://commons.wikimedia.org/wiki/ File:Stefan Lochner - Adoration of

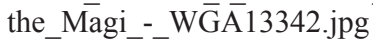

Ryc. 9. Fragment obrazu Pokłon Trzech Króli autorstwa Stefana Lochnera, ok. 1440. Źródło: Lochner S. 2019 , https://commons.wikimedia.org/wiki/ File:Stefan_Lochner_-_Adoration_of_ the Magi_-_WḠ̄A $13342 . j p g$

Konczewska ${ }^{29}$, this bag was found in an area not connected with the production of leather items ${ }^{30}$. The available data does not allow to state if the purse in question was made by a professional craftsmen or it was just home-manufactured for personal use. Neither we can say if the purse was made at the market square or in a completely different place, even though in medieval written sources from Wrocław there is quite a lot information about professional (guild-related) leather production ${ }^{31}$. This topic has been recently broadly discussed by Magdalena Konczewska $^{32}$. At the New Market Square itself, potential tanning production sites were recorded only in the oldest phases related to the functioning of the settlement (phase II and III) ${ }^{33}$. However, the existence of other production sites at the market square or the location of stalls (selling places) is questionable ${ }^{34}$. Nevertheless, the number of leather fragments in certain features (among others stratigraphic units 17 and 49) as well as in certain regions of the market

${ }^{29}$ Konczewska M. 2018a; Koncewska M. 2018 b.

${ }_{30}$ See Konczewska M. 2018b, p. 780, Fig. 690; p. 787, Fig. 692.

31 See Konczewska M. 2018b, also there more literature.

32 Konczewska M. 2018a; Konczewska M. 2018b.

33 Konczewska M. 2018b, p. 761.

${ }^{34}$ Kaźmierczyk J. 1966-1970; Konczewska M. 2018b, p. 778-781; see also Sawicki J. 2018. 
square $^{35}$ might indicate some kind of the leather production or at least distribution. It is, all the same, still impossible to discover, according to the available data, where and by whom the purse in question was made.

The simplicity of the item, especially in relation to other much more elaborate examples, and its poor quality, suggests that the purse was probably one of many items lost in a crowd at the market. It might have also been intentionally thrown away, as it is partially broken. The purse from Wrocław shows signs of repair and possible reuse of leather. Other pouches made of reused material are also known. One such specimen was found in Gdańsk at Jatki Mięsne ${ }^{36}$. It was made from good quality leather, originally being probably part of a shoe upper. However, it was re-stitched in a very unprofessional and simple manner ${ }^{37}$.

To sum up, the framed purse from Wrocław was probably a home-manufactured object. It seems to be the oldest known specimen, but other examples are known from (almost) contemporary iconography ${ }^{38}$. It is worth to note that purses shown in the iconographic sources seem to be elegant and high quality products. It is impossible to say if the strictly utilitarian function of the frames was adapted to more fashionable items or if it was just a fashionable trend being imitated using cheaper and more accessible materials.

We also cannot determine who consumed such simple items, nor how many of such items were in use and how common they were in relation to more elaborate examples. The absence of analogical finds suggests that they were very rare. However, it is reasonable to argue, opposite to the number of finds, that similar items were the most common bags used by the majority of society and most of such home-manufactured items are usually not preserved. Often they might also be unidentified and are in fact absent in archaeological assemblages. As being common, cheap and mundane, they also do not appear in written sources such as inventories, testaments, etc.

The answer to the question about the universality of such items is obviously not possible, especially when analysing a single, extremely rare artefact. However, it is worth considering some forgotten or even unpreserved items that may, in some way, distort the accepted image of the material culture of the Middle Ages.

Author's details:

Dr Jakub Sawicki

Archeologický ústav AV ČR Praha, v. v. i.

Letenská 4

11801 Praha 1

sawicki@arup.cas.cz

https://orcid.org/0000-0003-1198-0713

\section{BIBLIOGRAPHY}

Atlas historyczny miast polskich. 2001. Atlas historyczny miast polskich, vol. 4. Śląsk, issue 1 Wrocław. Wrocław.

Blusiewicz Karolina. 2017. Wyroby ze skóry i wytwórczość skórnicza w późnośredniowiecznym Pucku, [in:] Puck. Kultura Materialna małego miasta w późnym średniowieczu, ed. M. Starski, Warszawa, p. 305-360.

35 Konczewska M. 2018b, p. 782-783.

36 Ceynowa B. 2018, s. 479.

37 Ceynowa B. 2018, p. 494, Catalogue No 144, Fig. 23.

38 See Fig. 3 and note 11. 
Ceynowa Beata. 2015. Średniowieczna tradycja darów miłosnych na przykładzie bogato dekorowanych toreb skórzanych z Gdańska, [in:] In gremio - in praxi. Przedmioty skórzane na co dzień i od święta, ed. A.B. Kowalska, B. Wywrot-Wyszkowska, Szczecin, p. 75-96.

Ceynowa Beata. 2018. Zabytki skórzane, [in:] Jatki mięsne w Gdańsku od XIV do XX wieku, ed. A. Pudło, W. Ossowski, E. Trawicka, Gdańsk, p. 466-98.

Cowgill Jane, De Neergaard Margrethe, Griffiths Nick (eds.). 2008. Knives and scabbards, Woodbridge.

Douglas Mary, Isherwood Baron. 2002. World of Goods: Towards an Anthropology of Consumption, London.

Drążkowska Anna. 2009. Próba identyfikacji form średniowiecznych skórzanych toreb wydobytych w Toruniu na podstawie źródet ikonograficznych, [in:] In gremio — in praxi. Studia nad średniowiecznym skórnictwem, eds. A.B. Kowalska, B. Wywrot-Wyszkowska, Szczecin, p. 113-122.

Egan Geoff, Pritchard Frances. 2002. Dress accessories, c. 1150-c. 1450, Woodbridge.

Goubitz Olaf. 2009. Purses in Pieces. Archaeological finds of late medieval and 16th-century leather purses, pouches, bags and cases in the Netherlands, Zwolle.

Grew Francis, de Neergaard Margrethe. 2006. Shoes and pattens, Woodbridge.

Howell Martha C. 2010. Commerce before capitalism in Europe, 1300-1600, Cambridge.

Jervis Ben. 2017. Consumption and the 'Social Self' in Medieval Southern England, „Norwegian Archaeological Review", vol. 50/1, p. 1-29.

Kaźmierczyk Józef. 1966-70. Wrocław lewobrzeżny we wczesnym średniowieczu, cz. 1-2, Wrocław-Warszawa-Kraków.

Konczewska Magdalena. 2010. Sakiewki i torby, [in:] Ulice Średniowiecznego Wrocławia, eds. J. Piekalski, K. Wachowski, Wratislavia Antiqua, vol. 11, Wrocław, p. 244-245.

Konczewska Magdalena. 2018a. Odzież skórzana - obuwie, patynki, rękawice i inne elementy ubioru, [in:] Rytm rozwoju miasta na kulturowym pograniczu. Studium strefy placu Nowy Targ we Wroctawiu, ed. J. Piekalski, K. Wachowski, Wratislavia Antiqua, vol. 23, Wrocław, p. 794-850.

Konczewska Magdalena. 2018b. Rzemiosła skórnicze, [in:] Rytm rozwoju miasta na kulturowym pograniczu. Studium strefy placu Nowy Targ we Wrocławiu, ed. J. Piekalski, K. Wachowski, Wratislavia Antiqua, vol. 23, Wrocław, p. 747-793.

Kopytoff Igor. 2013. The cultural biography of things: commoditization as process, [in:] The social life of things: commodities in cultural perspective, ed. A. Appadurai, Cambridge, p. 64-92.

Kowalska Anna B. 2015. Średniowieczne rzemiosło obuwnicze na Pomorzu. Zarys problematyki, [in:] In gremio - in praxi. Przedmioty skórzane na co dzień i od święta, eds. A.B. Kowalska, B. Wywrot-Wyszkowska, Szczecin, p. 13-27.

Mackiewicz Maksym, Marcinkiewicz Kamila, Piekalski Jerzy. 2014. Plac Nowy Targ we Wrocławiu w świetle badań wykopaliskowych w latach 2010-2012, „Archaeologia Historica Polona”, vol. 22, p. $167-184$.

Marcinkiewicz Kamila, Piekalski Jerzy. 2018. Przemiany placu w późnym średniowieczu i w czasach wczesnonowożytnych w świetle stratygrafii nawarstwień, [in:] Rytm rozwoju miasta na kulturowym pograniczu. Studium strefy placu Nowy Targ we Wrocławiu, eds. J. Piekalski, K. Wachowski, Wratislavia Antiqua, vol. 23, Wrocław, p. 152-194.

Marcinkowski Mirosław. 2009. Stan badań nad średniowiecznymi przedmiotami ze skóry odkrytymi w Elblagu, [in:] Studia nad średniowiecznym skórnictwem, eds. A.B. Kowalska, B. Wywrot-Wyszkowska, Szczecin, p. 167-192.

Rytm rozwoju miasta. 2018. Rytm rozwoju miasta na kulturowym pograniczu. Studium strefy placu Nowy Targ we Wrocławiu, eds. J. Piekalski, K. Wachowski, Wratislavia Antiqua, vol. 23, Wrocław.

Sawicki Jakub. 2014. Ramki torebek i portmonetek z fosy na placu dominikańskim we Wrocławiu, „Śląskie Sprawozdania Archeologiczne”, vol. 56, p. 301-312.

Sawicki Jakub. 2018. Organization of production and trade of minor metal items at Nowy Targ (New Market) Square in medieval Wroctaw in the light of the production waste, "Archeologické rozhledy", vol. 70/1, p. 110-134.

Social life. 2013. The social life of things: commodities in cultural perspective, ed. A. Appadurai, Cambridge. 
Wachowski Krzysztof. 2013. Emblemata mediaevalia profana: przykład Polski, Wrocław. Wywrot-Wyszkowska Beata. 2008. Skórnictwo w lokacyjnym Kołobrzegu. XIII-XV wiek, Szczecin.

\section{Internet pages:}

Herman (Hermann) Brother. 2019. Pewtler (Beutler), [in:] Die Hausbüchern der Mendelschen und Landauerschen Zwölfbrüderhausstiftungen, Stadtbibliothek Nürnberg, Amb. 317.2 ${ }^{\circ}$ Folio 21 verso, http://www.nuernberger-hausbuecher.de/75-Amb-2-317-22-r/data (access 15.10.2019).

Jagdtasche. 2019. Jagdtasche, Kunsthistorisches Museum in Vienna, Inventory No Hofjagd- und Rüstkammer, D 7, www.khm.at/de/object/722ea9ceb2/ (access 15.10.2019).

Lochner Stefan. 2019. Adoration of the Magi, Collection of Cologne Cathedral, Wikimedia Commons: https://commons.wikimedia.org/wiki/File:Stefan_Lochner_-_Adoration_of_the_Magi_WGA13342.jpg (access 15.10.2019).

Schwedler Abraham. 2019. Jagdtasche, Dresden, Staatliche Kunstsammlungen, Historisches Museum, Inventory No. X163, Bildindex, https://www.bildindex.de/document/obj32005248?part=0\& medium $=$ mi10065a12 (access 15.10.2019).

Rosenheim Kunz von. 2019. Kuntz von Rosenheim, [in:] Große Heidelberger Liederhandschrift (Codex Manesse), Universitätsbibliothek Heidelberg, Inventory No Cod. Pal. germ. 848, B1. 394r, http://digi.ub.uni-heidelberg.de/diglit/cpg848/0783 (access 15.10.2019).

Tacuinum Sanitatis. 2019. Tacuinum Sanitatis, Paris, Bibliotheque Nationale de France, Département des manuscrits, Nouvelles acquisitions latines, manuscrit 1673, fol. 47, http://expositions.bnf.fr/ gastro/grands/033.htm (acces 15.10.2019).

\section{Unikatowa późnośredniowieczna sakiewka z ramką z placu Nowy Targ we Wrocławiu}

Niniejszy artykuł dotyczy sakiewki z ramką (ring-framed purse), która została odkryta w trakcie badań ratowniczych prowadzonych na placu Nowy Targ we Wrocławiu, w latach 2010-2012. Sakiewki tego typu w zasadzie nie są obecne w polskiej literaturze archeologicznej, a znaczna część analogicznych przedmiotów pochodzi z zagranicznych kolekcji muzealnych. Sakiewka z Wrocławia, w przeciwieństwie do znanych egzemplarzy przede wszystkim z Anglii i terenu współczesnych Niemiec, ma drewnianą ramkę, a wykonana jest ze skóry niezbyt wysokiej jakości. Ciekawa jest biografia przedmiotu. Omawiany zabytek pochodzi z nawarstwień datowanych na drugą połowę XIII-początek XIV w., zaś inne, notowane egzemplarze są znacznie młodsze — z końca XV-XVI w. Badacz, Olaf Goubitz, zaznacza, że sakiewki te pojawiają się dopiero po roku 1425. Znane są jednak także ze starszego źródła - z tzw. Codexu Manesse datowanego na lata 1300-1340. Datowanie to dobrze koresponduje $\mathrm{z}$ wrocławskim znaleziskiem.

Wszystkie dane i pośrednie analogie wskazują, że omawiany przedmiot jest produktem przydomowej wytwórczości, wykonanym na własne potrzeby. Biorąc pod uwagę wczesne datowanie tego egzemplarza, zwłaszcza w stosunku do zachowanych egzemplarzy muzealnych i większości okazów ze znanych przedstawień ikonograficznych, można rozważać, czy sakiewka z drewnianą ramką jest rzadkim naśladownictwem bardziej luksusowych wyrobów, czy też stanowiła powszechny przedmiot użytkowy, który jest sporadycznie rejestrowany wśród źródeł archeologicznych i pisanych.

Problemu tego nie można rozstrzygnąć analizując jeden zabytek, warto jednak pamiętać o zapomnianych lub „niezachowanych” przedmiotach, które w pewien sposób mogą zmienić znany nam obraz kultury materialnej średniowiecza. 